\title{
Selecting Program of Study for Undergraduate Students in the Valley View University, Kumasi
}

\author{
Yeyie Patrick \\ Social Studies Department, Kibi Presbyterian College of Education, Ghana \\ E-mail: patyeyie@gmail.com
}

Received: 15 July 2021; Revised: 25 August 2021; Accepted: 28 August 2021

\begin{abstract}
The paper investigates the selection of courses of study by undergraduates of Valley View University, Kumasi. Data were collected from the school of social science education which focused on 10\% of the total population, two hundred and ten (210). The data were analyzed using the Statistical Package for the Social Sciences (SPSS) version. 20. Findings of the study reveal that economic influence has been found the most important allied to the desired choice of the programme of study. Other factors include school, peer and gender influence. It further argues that, for students to have access to their preferred program of study, there should be E-learning, academic guidance, orientation and avoidance of family influence. The study further recommends that families should serve as guides and support their wards in the selection of courses rather than imposing various programmes on them due to reasons such as sustainment of family business. In addition, Ghana Education Service (GES) should inculcate guidance and counseling into the Senior High School (SHS) syllabus to enhance prior knowledge on the selection of course or programme of study in the tertiary institutions and organizations of career exploration activities to help them decide on the programme of study.
\end{abstract}

Keywords: choice of programme, undergraduate, universities, pursue, urged

\section{Introduction}

It has been argued that the status of universities is based on the number of students admitted. With this in mind, Kallio (1995) explains that among the selection of education courses, "the student's decision" is influenced by the selection of the student's program. In Spain, Sanchez (2012) analyzed the selection of courses of secondary school students' choice of higher education courses. According to Alberts et al. (2002) individual desire, family, colleagues, and schools may all affect learners' future occupational selection. Studies conducted by Malgwi, Howe, and Burnaby also suggest that families do impact greater influence in students' selecting various undergraduate courses than the teachers who are supposed to guide them in their course.

There appears to be fierce competition among universities to recruit brighter students and students face stiff competition to be admitted to prestigious universities.

For many high schools, gathering information for a study becomes a real challenge. Family members, classmates, teachers and people from the economic community in the immediate environment are involved in the process. Some of them help make the decision, while others criticize it. Parents create favorable conditions, while faculty advice and

Copyright (C2021 Yeyie Patrick

DOI: https://doi.org/10.37256/ser.2220211042

This is an open-access article distributed under a CC BY license

(Creative Commons Attribution 4.0 International License)

https://creativecommons.org/licenses/by/4.0/ 
fellow students influence a prospective applicant's choice of college. However, each undergraduate student ultimately makes his or her own decision in choosing a program of study.

The choice of the study program for Ghanaian undergraduates may account for the graduate unemployment and the recent establishment of the Unemployed Graduates Association in the country. The Minister of Health has made it clear that the country is producing unemployable graduates, leading to what he calls the "Unemployed Graduates Association" (Daily Graphic, 2010). This decision to take a course of study at university has a great impact on their whole life. The process of choosing a course of study for an undergraduate student is one of the key decisions a student makes in his or her life that may or may not determine that person's future. Such decisions can be quite complex, especially when students do not have any guidance in choosing a program of study. In the context of this study, some of the courses being taken at the Valley View University Kumasi are humanities, language, arts, business and many others.

Over the past two decades, Ghana has seen significant growth in higher education, both in terms of enrollment and infrastructure. A significant portion of this growth has come from the private sector. The University offers programs and awards certificates up to the doctoral level. Students are admitted on the basis of their performance in the West African Examinations Council (WAEC) Exams. Most undergraduate students who are not offered their preferred program of study are either persuaded by intrinsic or extrinsic motivation to accept the available program placement, but not necessarily the program of their choice.

Because of the important role that undergraduate students' program choices play in their lives and the nation as a whole, questions about program choice should not be taken for granted. Therefore, the study investigates the selection of study of undergraduates at Valley View University-Kumasi. It was observed that although undergraduate course choice is an important component of student welfare and management, it has not received the necessary research attention.

\subsection{Statement of the problem}

Many countries around the world, especially in the West, spend a great deal of money on providing guidance and counseling to students in the selection of undergraduate programs of study. Before the arrival of the Europeans who introduced formal education, education in Ghana was largely informal and based on apprenticeships. Ghana's rapid transition from an informal to a formal economy made education an important political goal. Ignorance about the choice of the program of study may not lead to happiness, and it is better to be informed about the program of study than to be left to chance. Choosing a program of study is not easy, and many undergraduate students are unable to articulate their choice of the program of study. One of the major turning points in life is the selection of an occupation.

It helps to position yourself strategically in seeking job opportunities. When choosing a program of study for an undergraduate student, the decision is often made by the student and most of the time by the parents. However, this decision plays a key role in building one's future and career. Choosing an inappropriate program of study can lead to frustration in one's learning process and in finding a job. Most of the time, people choose what is available rather than what matches their personal interests, values, abilities and skills.

\subsection{Problem justification}

The study makes sense because of the growing number of unemployed graduates in the country. A study in Ghana also shows a large number of students may take up to 10 years to find jobs due to various challenges including lack of employable skills, lack of access to start-up capital, poor graduate attitudes towards job opportunities, and low capacity of the industry to absorb large numbers of graduates.

Joblessness is a problem for the country. It has been noticed that most of the literate unemployed in the country are due to the courses they took while in school. Most undergraduates do their courses in school because of their eagerness to continue their formal education, their desire to be known as graduates, and the influence of their peers. This alarming increase in the membership of the Association of Unemployed Graduates has put pressure on the government and the economy. It has also led to many social vices in the country. For example, the number of young women engaged in prostitution, fraud, drug trafficking and armed robbery is growing at an unimaginable rate. Illegal activities such as those mentioned above are on the rise due to the high unemployment rate in the country, says Professor Peter Quartey. 


\subsection{Purpose of the paper}

The study investigates the selection of programs by undergraduate students in Ghana. The study was based on the increase in membership of the Association of Unemployed Graduates in the country. It is hoped that the study will bring to light the institutional arrangements that exist for undergraduate students to choose their courses of study.

\subsection{Objectives of the paper}

The paper seeks to:

1. Investigate preferred study program of students of Valley View University College of Education-Kumasi.

2. Determine the selection of a course of study of undergraduate in the College of Education-Kumasi at Valley View University.

3. Propose ways to improve students' ways of selecting a preferred course of study.

\subsection{The study questions}

1. Which study programs are most preferred by undergraduate students in the College of Education-Kumasi at Valley View University?

2. What factors influence the choice of study programs by undergraduate students at Valley View University College of Education-Kumasi?

3. How do students register at Valley View University for their chosen course of study?

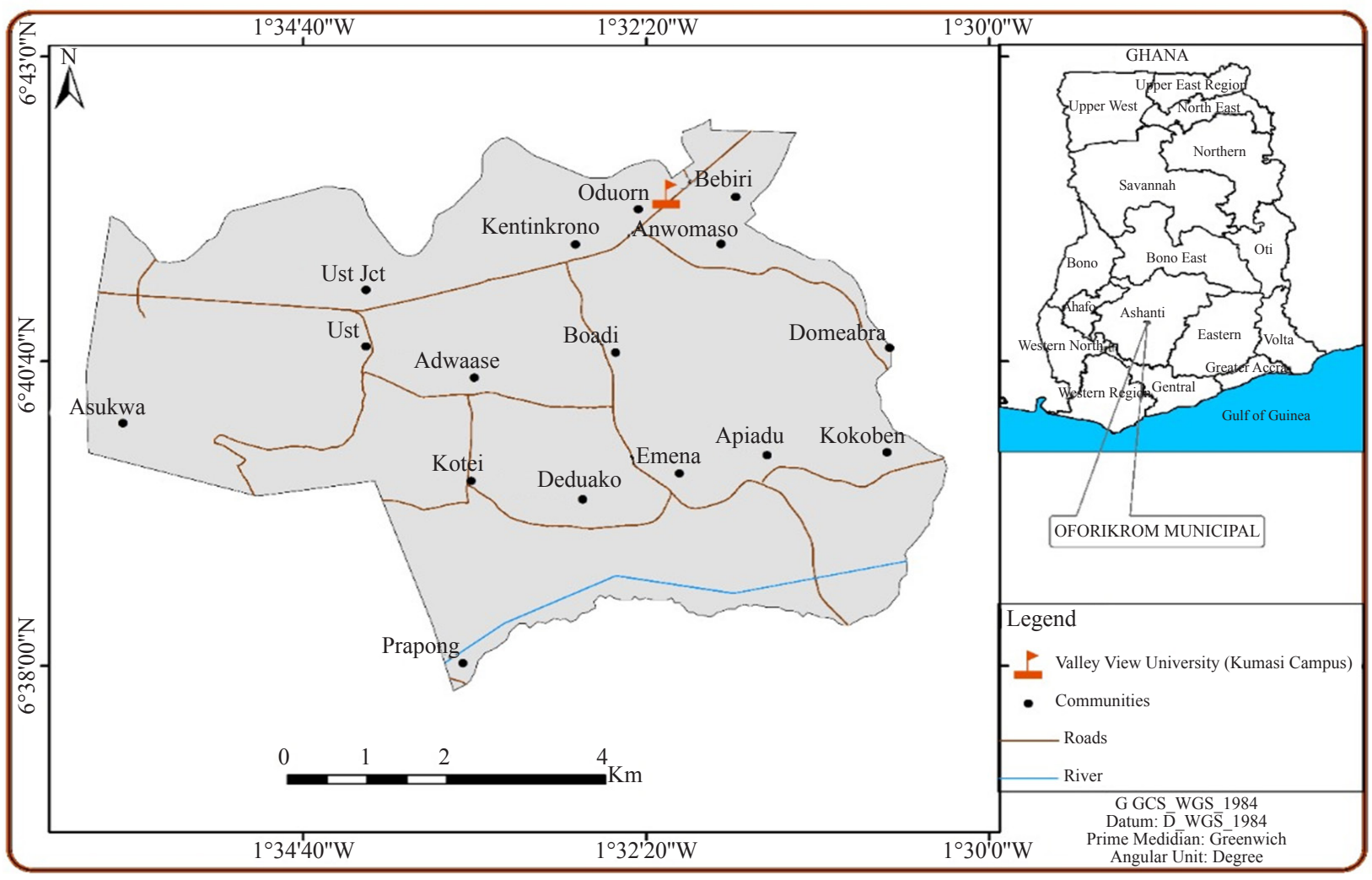

Figure 1. Map of Oforikrom municipal 


\subsection{Significance of the paper}

The paper is important for improving the understanding of the factors that influence undergraduate students' course choices. It will help to understand the particular challenges that undergraduate students at the Valley View University, Kumasi face in choosing courses of study and will also help to reveal the consequences of their choices. It will also inform parents, guardians and the government of the need to help undergraduate students choose their courses of study and the need for the government to focus on investing in career guidance for students.

\subsection{Study area}

Valley View University is one of the extended campuses established in 2004 in Kumasi, Oforikrom, Ghana, operating a center for adult and distance education programs. The Kumasi campus currently enjoys accreditation and recognition by the National Accreditation Board (NAB) and the Adventist Accreditation Association (AAA).

\subsection{Location and size of the district}

The Municipality of Oforiklen is one of the forty-three (43) metropolitan, municipal and district councils in the Ashanti Region. It was carved out of the former Kumasi City Council. The Valley View University is located in Odoum in the Oforikrom Municipality. Figure 1 above is a map of the Oforikrom District of Ashanti Region.

\section{Literature}

The review was done under the following headings:

- Factors influencing undergraduate students' selection of courses of study.

- The preferred programmes of study by undergraduate students.

- Suggest ways of improving student's access to their preferred programme of study.

\subsection{Factors that compel the choice of the programme of study for undergraduate students}

Alika (2010) noted that there was no significant relationship between the influence of parents and peers on secondary school students' career choices in the humanities and suggested that counselors should work directly with parents and peers, especially to reinforce positive aspects that may ultimately improve the career prospects of our future workers. This suggestion seems to be in line with the study of Akyina et al. (2014), who stated that school counselors should reinforce students' rational course selection behavior by strengthening school guidance to enable learners to do rational selections.

Undergraduates try to establish their identity and define whom they are by establishing themselves, both to themselves and to the world, and often painful and critical task that can sometimes depend on their peers. There are many new challenges in choosing the right program of study, achieving the required grades, and selecting the right school for the right course of study. The issue of peer groups raises some questions in order to understand the behavioral and attitudinal development at the transitional stage of persons. Most undergraduate students find themselves at this stage of adolescence and therefore they face the general problems of adolescence. Classen \& Brown (1985), as well as Brown (1982) attempted to identify the stressors that adolescents encounter.

This paper made some suggestions of types of students' stress:

-Pressure to participate in school academic and extracurricular activities.

-Pressure to engage with family members.

-Pressure to conform to peer pressure in the culture.

-Pressure in inappropriate behaviors, for instance, criminal activity.

It can be inferred from the study that most undergraduate students were influenced by their peers in the choice of course of study. In terms of pro-social behavior, researchers have noted in their studies that peers influence each other in terms of academic engagement, sharing, cooperation, participation in extracurricular activities, and sexual abstinence, 
all of which are pro-social activities (Bryant \& Bell, 2006; Carlo et al., 1998; Ellis \& Zarbatany, 2007). Peer conformity, sometimes referred to as peer pressure, occurs when individuals choose to adopt the attitudes or behaviors of others under real or imagined pressure. Peer influence is greater in adolescence than at any other time in life. The quality of adolescents' relationships with their peers, and the types of peers they interact with, play an important role in helping or hindering their current and future functioning.

Role modeling is considered to be an important influencer in future life determinants, including a choice among disciplines, self-employment choices. Model is defined as those whose lives and activities influence respondents' decisions, "people who are worthy of emulation in some area of life" or "roles that are considered to be in one or a selected number of an ideal standard of real or theoretical characters to emulate" (American Psychological Association, 1982). Parents and other family members, peers, and teachers have been identified as possible direct role models. As such, they have been included in the Role Model Influence Scale (IRMS) (Basow \& Howe, 1979) and the Career Influence Inventory (CII) (Fisher \& Stafford, 1999). However, less well-known individuals, such as historical or famous figures, may also constitute valid role models.

Role models pose an important challenge when it comes to studying in a particular area of study. According to Kokaly (2001), college learners in the United States are able to identify the academic and career decisions that most influenced their role models. Hackett et al. (1989) study of female college learners in America supports the idea that the influence of female role models is a strong predictor of women's course and suggests that role models are required, especially in selecting nontraditional careers. Additional evidence supporting the role model effect is seen in the ways in which measures put in place can change decisions.

\subsection{The preferred programmes of study by undergraduate students}

In Spain, Sanchez (2012) analyzed the factors that influence secondary school students' choice of higher education. The study explored the meaning and benefits of a supplier-client relationship between universities and students. The study revealed that the most important criteria for Spanish students interested in pursuing communication studies were the ranking, reputation, excellence and quality of the university's educational program. The results of the study are consistent with those of Maringe (2006) and Holsworth and Nind (2006), who observed that sources of information related to degree programs place the greatest importance on direct and empirical sources and give preference to public universities over private ones.

Other researchers also explored the link between students' commitment to architectural education and their subsequent willingness to stay in the profession. The findings revealed a correlation between the reasons for choosing architecture and the reasons for deciding to pursue it. The study found that at higher levels of study, students' desire to practice architecture gradually decreased.

The desire to practice architecture gradually decreases at higher levels of the study compared to lower levels of study. The authors suggest that in order to improve retention of professional practice, the admissions process should require applicants to provide a detailed personal statement to establish strong consistency.

Establish a strong alignment between the chosen program/major and career aspirations. Within the local context, how students choose courses and the factors that may influence them are not similar.

What factors may have changed learner's choice of study in the built environment?

Sabir et al. (2013), found in the study on factors influencing college and course selection among undergraduate students in engineering and business majors. The main focus of the study was to reveal the factors that students consider important in relation to their choice of university and ideal course. They found that among the key marketing factors for universities, students considered prominence, price and course factors to be the most important. This study implies that promotional tools should be designed based on student preferences rather than policies that universities consider important to students and that institutions need to reposition themselves in a competitive education marketplace.

According to Coetzee and Beukes (2010), the concept of employability has emerged as an important contributor to career success and satisfaction in a progressive, generally insecure, and disorganized occupational environment. Furthermore, McArdle et al. (2007) asserted that occupational adversity and adaptability are key aspects of an individual's employability. Employability satisfaction is defined as a person's level of self-perception that they possess attributes, skills, knowledge, experience, and occupational expertise that can easily create or attract employment 
(Schreuder \& Coetzee, 2011), and the extent to which enrollment in a program implies a student's commitment to a particular career. One suspects that for many undergraduates, coming to college to further their education is a poor second choice. To be sure, however, the evidence for this suspicion is usually unfounded. Most students are well aware that they have easy access to job opportunities and have little doubt that the programs they take are the best way to get those opportunities.

In addition, of those students who are accepted to college, many are not completely satisfied for the reason that it is the best way to prepare for the future, and many achieve a sense of single-mindedness in following a course or program leading to a career that they find more appealing than they thought. It is clear that the course or program an undergraduate student chooses is geared toward the career he or she has in mind. In other words, an economics student expects to be an economist, a geography student expects to be a geographer, a history student expects to be a historian, and so on.

\subsection{Ways of improving students' access to their preferred programme of study}

There is a long history of research on comparative goals in distance education and face-to-face instructional settings, dating back to the 1920s. The results of hundreds, perhaps thousands, of studies have been consistent over the last several decades and into the 1990s.

There were no significant differences in academic performance among students who participated in face-toface instruction. No vast difference in performance among learners who took part in both structured and unstructured education. The above may be true despite the difference in the application and mode of learning by the student. A number of researchers reviewed and analyzed and concluded that online learning is the best compare to the rest.

Online learning is education that takes place over the Internet. It is often referred to as "E-learning" or other terms. However, online learning is only one type of "distance learning". That is a general term for any learning that takes place across a distance rather than in a traditional classroom.

Online learning is one of the ways that can help improve students' access to their preferred course of study.

Article published by digitalmarketinginstitute.com on May 30, 2018, shows that E-learning is simple to manage. Those days when students had moved to a particular location to study, despite the distance from where he or she lives, what their financial resources are, or whether they can't get to class early in the morning, online learning enables educators to provide them with the opportunity to learn on their own. In self-paced courses, there is no expectation of attendance. With online learning, they can study in the evenings, on weekends, or in whatever way they choose to fit their existing lives. Flexible schedules also mean that instructors can teach from the comfort of their homes and work outside of the traditional classroom, allowing more freedom to pursue other interests during the day. In addition, E-learning improves digital literacy. Students who can use online tools effectively have much to gain in the workplace. While certain roles require specific digital skills, such as marketers and those who work in IT, most roles in business require some level of digital literacy. Online learning helps improve digital literacy because it gives students an understanding of how to effectively communicate with content, peers and mentors online. Since digital literacy is quickly becoming the most valuable tool for lifelong learning, improving competency is a worthwhile investment for students and faculty.

The suggestion above indicates that the preferred learning option for students could be improved by creating more opportunities for students to learn online, as traditional classrooms are unnecessary if universities were able to adopt a variety of E-learning options.

Early research on distance learning concluded that these technologies were not significantly different in effectiveness from regular classroom learning. Policymakers reasoned that if online instruction was not worse than traditional instruction in terms of student achievement, then online education initiatives were justified based on costeffectiveness or the need to provide learners with opportunities where face-to-face instruction was not feasible. In addition, with the development of web-based and collaborative technologies, policymakers and practitioners want to understand the effectiveness of interactive Internet-based online learning approaches and need to understand the conditions under which online learning is effective, and the following are key findings.

-Studies in which online instruction was collaborative or instructor-led had greater effects than those in which online learners worked independently.

-Most changes in the way online learning was implemented across studies did not have a significant impact on 
student learning outcomes.

Motivation refers to behaviors that are driven by internal rewards. In other words, the motivation to engage in behavior comes from within the individual because it naturally makes you feel satisfied. The above indicates that the individuals undergo intrinsic motivation. They want to do the work because the benefit is consistent with their beliefs or satisfies their desires so they place great importance on it. With this, the student's desire to do the project is due to the belief system and willingness to fulfill a specific desire, such as the desire to feel important in society, the power to influence others and the need to be accepted and respected in society.

Environmental urge implies an external source of inspiration. Meaning, the desire to do something is controlled by outer stimuli. We should be aware that stimulus comes from an external source whose outcome of performing a work brings rewards. Thus, intrinsic and extrinsic motivation are the two main factors that can improve a student's chances of entering a preferred undergraduate program. In addition, the government should reach out to universities to offer scholarships to deserving but poor students who are interested in pursuing courses that involve a lot of money, such as medicine, law, and engineering.

Education departments and various examination bodies across the globe should review their mark lines that prevent many students from studying the courses they prefer. For example, a student wishes to study medicine but his/her results disqualify him/her, thus dashing his/her dreams and ambitions.

\subsection{Summary of literature}

The review highlights the selection of courses by undergraduate students when it comes to course of study. Parents influence undergraduate students' choice of course of study is discussed, as well as the ways how peers influence their choices. In addition, career and job opportunities are also examined as factors, and how role models influence undergraduate study choices. Finally, ways to improve student access to preferred courses, such as E-learning, and motivation, are also discussed.

\section{Methods}

The unit presents procedures employed for the data collection process. It encompasses the following subheadings: the research approach, research design, sources of data, just to mention but a few.

\subsection{Design}

The design was a case study design. This involves the triangulation of quantitative and qualitative methods. Creswell (2009) states that quantitative research designs test objective theories by examining the relationships between variables. Qualitative research attempts to understand the social reality on its own terms, as it does; providing a rich description of people and interactions in the natural environment (Holstein \& Gubrium, 1997). Triangulation focuses on the collection and analysis of qualitative and quantitative data within the same research (Creswell, 2003). In this study, the idea of triangulation comes with the belief that by deploying more than one method of data collection, the validity and confidence level of the findings can be increased (Bryman \& Bell, 2006). Some criticisms of triangulation are that even if the results from different data sources are consistent, there is no guarantee that the result may yield two incorrect but similar conclusions (Blaikie, 2000). Despite these criticisms, there are many compelling reasons to support the triangulation approach. For example, Creswell (2003) asserted that triangulation allows researchers to arrive at the same findings. In addition, researchers use at least three researcher methods, thus interviewing the same people or evaluating the same evidence reduces the impact of personal bias (Golafshani, 2003), which indicated that using triangulation lies in the in-depth description and insight into the issue under study.

\subsection{Population}

The respondents consist of learners among the institution for which the survey was identified. The population is the total number of units from which the sample was obtained (Ofori \& Dampson, 2011). The population for this study 
consisted of all undergraduate students from 100 to 400 levels in the College of Education at Valley View University in Kumasi. The number of students in this college is about 700 (seven hundred), of which about $60 \%$ are male and $40 \%$ are female.

\subsection{Sample}

The sample was part of the population selected for the study (Ofori \& Dampson, 2011). This study selected 30\% of the undergraduate students in the College of Education. It involved first, second, third and final year undergraduate students. This would constitute a total population of 210 students.

\subsection{Sampling technique}

A combination of stratification, quotas and simple random samples was used in this study. First, students in the College of Education were stratified into 100, 200, 300, and 400. An appropriate quote is given to each stratum and a simple random method is used to select the required number from each stratum. This technique implies that all subjects are giving the equal chance of being selected for the study. It requires a sample large enough to ensure that the sample reflects the population (Pittenger, 2003). Conceptually, simple random sampling is the simplest probability sampling technique. It requires a complete sampling frame. It has the advantage that there are no classification errors, and it requires the least advanced knowledge of the population other than the frame. Its simplicity also makes it relatively easy to interpret the data collected through the lottery technique.

\subsection{Instruments for data collection}

A questionnaire was designed as a research tool. Guided by the research objectives, the questionnaire was the most appropriate research tool as it was mostly used to collect information for quantitative research. The questionnaire was administered personally to the respondents to minimize mistakes and stress and to make sure a maximum level of distribution is done. Closed-ended questions were used in the questionnaire framework. Respondents were asked to provide answers to questions posed under each objective of the study: students' preferred study programs and selection of learners program of study. The Section A of the questionnaire asked for personal information about the respondents, Section B collected information about the respondent's preferred study program, and Section C asked about the factors that influenced the respondent's choice of the study program. Finally, Part D asks for measures to ensure that prospective students have access to the program of their choice.

\subsection{Methods for data presentation and analysis}

Part A of the questionnaire contains information about the respondents' personal data, which were analyzed using tables and illustrations based on the findings. For Part B, tables were also used to show the results of respondents' preferred study programs and whether they are the ones respondents are currently studying. In order to analyze the factors influencing the choice of study programs, bar charts were used.

Data from interviews and field observations were analyzed qualitatively, mainly through direct quotes from respondents and descriptions of events in written form. In terms of quantitative techniques, raw data collected through questionnaires were coded and entered into the Statistical Products for Service Solutions (SPSS) software. Subsequently, several tools of the SPSS version. 20 software were also used to analyze the input data. The results of the analysis of the collected qualitative and quantitative data were presented in the form of frequency tables, pie charts, bar charts and pictures to provide a visual impression of the collected information.

\subsection{Ethical consideration}

In every research study, the ethics of the researcher is a very important aspect to ensure that the research process and the results of the study are trustworthy and valid. Research ethics are the rules and regulations that govern the methods, procedures, or perspectives that determine how the data used to address the research questions are collected 
and analyzed (Resnik, 2015).

Participants were given full information about the nature of the research. The study participants had information on the significance of the research. Thus their inputs were required for anyone who wants to help students choose the best program of study and to suggest possible solutions. Anonymity, confidentiality, and impartiality were highly valued. Anonymity is a situation in which the researcher is unable to link the data to the respondent. This is when privacy is respected and the identity of the respondent remains anonymous. Permission was sought from the institution before the research was carried out.

\section{Findings and discussions}

Data were collected through questionnaires and field observations. The researcher used tables or figures were necessary to present the results to help the reader summarize the findings from the field. This chapter begins with student personal data and then presents the general findings item by item.

\subsection{Socio-demographic data of respondents}

In this study, the only respondents in this category were students. Items one finds out their gender. Figure 2 gives the details. Below are the details of the participants in the study. Gender was important in this study because the researcher wanted to know if it had any influence on the study. The Table 1 below shows that there were 112 males and 98 females. This result means that more males than females participated in the study.

The gender distribution is shown in Figure 2.

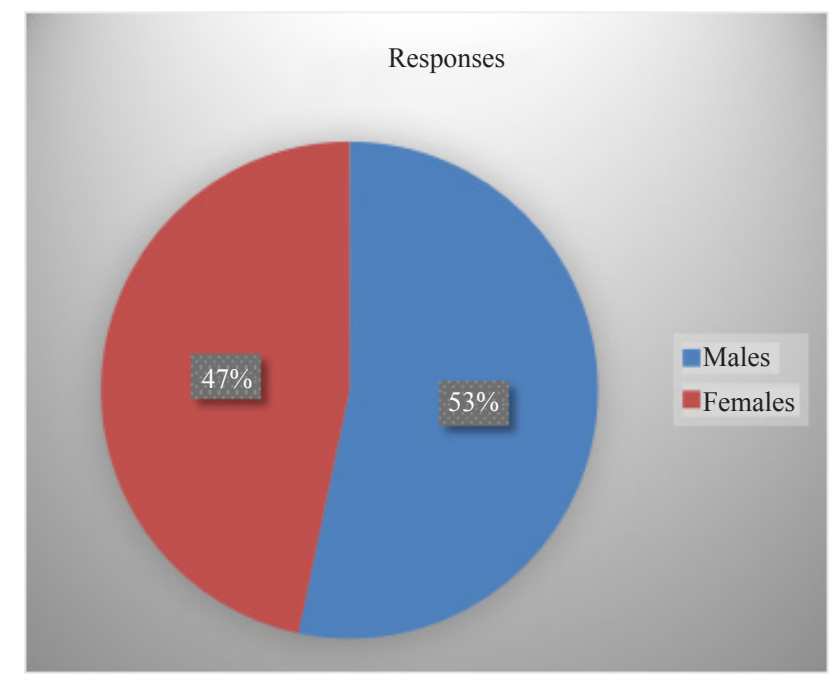

Source: Field Data (2021)

Figure 2. Distribution of respondents by gender

Table 1 below indicates that the majority of students for the study were between ages 30-39 years old, accounting for $53.8 \%$. Those between the ages of 30-39 responded more frequently to the questionnaire. The questions were quantitative in nature, with most of the items requiring only a "yes" or "no" answer. Most students were able to read the questionnaire on their own without difficulty. 
Table 1. Age of the respondents, distribution of respondents by age

\begin{tabular}{ccc}
\hline Responses & Frequency & Percent $(\%)$ \\
\hline Less than 18 yrs & 4 & 1.9 \\
$19-29$ & 82 & 39.0 \\
$30-39$ & 113 & 53.8 \\
40 and above & 11 & 5.3 \\
Total & 210 & 100 \\
\hline
\end{tabular}

Source: Field data (2021)

\subsection{Level of students}

In this study, the researcher tried to determine the number of levels of the students who participated in the study. The results of the study are shown in Figure 3.

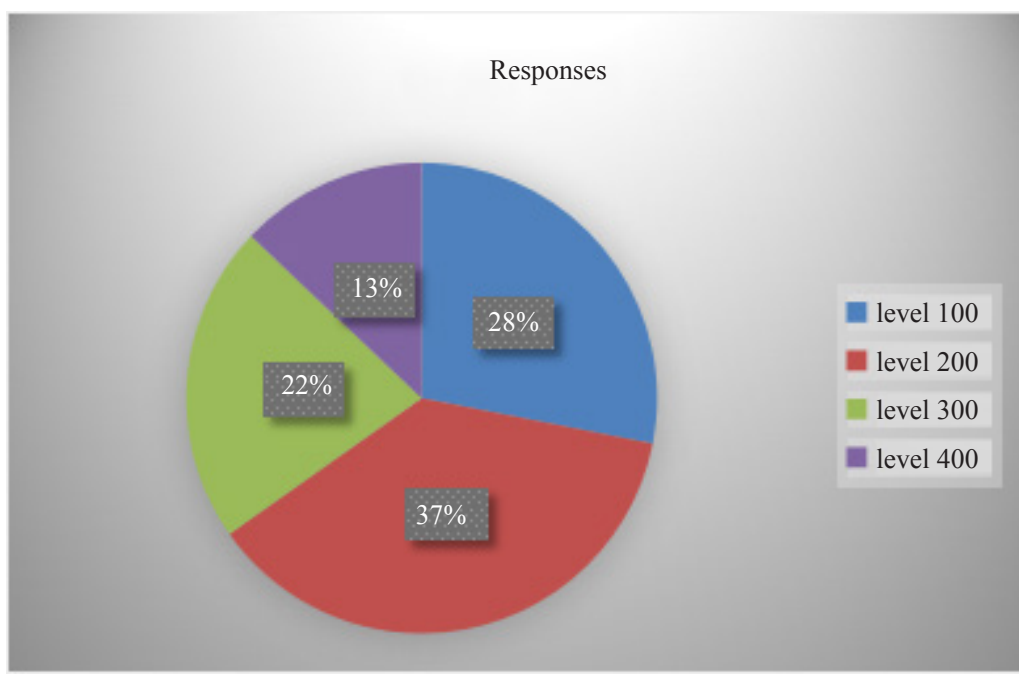

Source: Field Data (2021)

Figure 3. Level of students

$28.1 \%$ were 100 -level students, while $37.1 \%$ were 200 -level students. In addition, $21.9 \%$ were 300 -level students and $12.9 \%$ were 400 -level students. These results indicate that the majority of respondents were 100 and 300 levels. This is because they are recently admitted students to the university and their opinions were very important. Also, 300 and 400-level students were taken into consideration because they have been around for a while compared to first and second-year students. Therefore, they have already experienced the impact of various study programs. In addition, 400-level students are leaving college and can share their experiences with students from high school and the community at large.

\subsection{Current programme of study}

The details of the findings are shown in Table 2 below.

From the below, Social Studies, English and Religion were the highest number of students as indicated by the respondents, while Mathematics and Accounting had the lowest number of students. This may be because more students are willing to study Sociology, English and Religion than Mathematics and Accounting. 
Table 2. Current programme of study

\begin{tabular}{ccc}
\hline Responses & Frequency & Percent $(\%)$ \\
\hline English & 59 & 28.1 \\
Social studies & 63 & 30 \\
Mathematics & 32 & 15.2 \\
Religion & 38 & 18.1 \\
Accounting & 18 & 8.6 \\
Total & 210 & 100 \\
\hline
\end{tabular}

Source: Field Data (2021)

\subsection{Studying desired programmes}

The researcher also wanted to find out if students are really studying their desired programmes. Table 3 below gives the details of the findings.

Table 3. Studying desired programme

\begin{tabular}{ccc}
\hline Responses & Frequency & Percent (\%) \\
\hline Yes & 172 & 81.9 \\
No & 38 & 18.1 \\
Total & 210 & 100 \\
\hline
\end{tabular}

Source: Field Data (2021)

From Table 3 above, the majority of students (81.9\%) in the College of Social Science Education offered their preferred course, while a minority of students $(18.1 \%)$ did not take the course they preferred. According to some respondents, their families, friends and role models influenced them to read the current course of study. What's more, the school gave them the opportunity to do so because they did not meet the cut-off score for their desired course. On the other hand, $81.9 \%$ were studying their desired course because they had prior knowledge of the course and were guided by their school counselor. This enabled them to choose their preferred course.

\subsection{Excitement of programme}

Another item the study addressed was to find out if students are excited about their selected area of study. Results are presented in Table 4 below.

In every institution, it is important that students enjoy their learning sessions. With this in mind, the study found out the level of students' excitement about their study courses. Table 4 clearly shows that most of the respondents were very satisfied with the courses they were offering as $57.6 \%$ and $26.7 \%$ of the respondents strongly agreed and agreed respectively. This is because most of the respondents believe that the courses they were offering will help them get desired job opportunities and good salaries in the future.

Conversely, the minority who strongly disagreed and disagreed indicated that they were either forced to offer the course or did not have in-depth knowledge about it and, therefore, not happy. 
Table 4. Excitement about the programme

\begin{tabular}{ccc}
\hline Responses & Frequency & Percent $(\%)$ \\
\hline Strongly agree & 121 & 57.6 \\
Agree & 56 & 26.7 \\
Disagree & 17 & 8.1 \\
Strongly disagree & 16 & 7.6 \\
Total & 210 & 100 \\
\hline
\end{tabular}

Source: Field Data (2021)

\subsection{Change of programme}

The researcher also tried to find out whether students were to change their programme or continue with the programme of study.

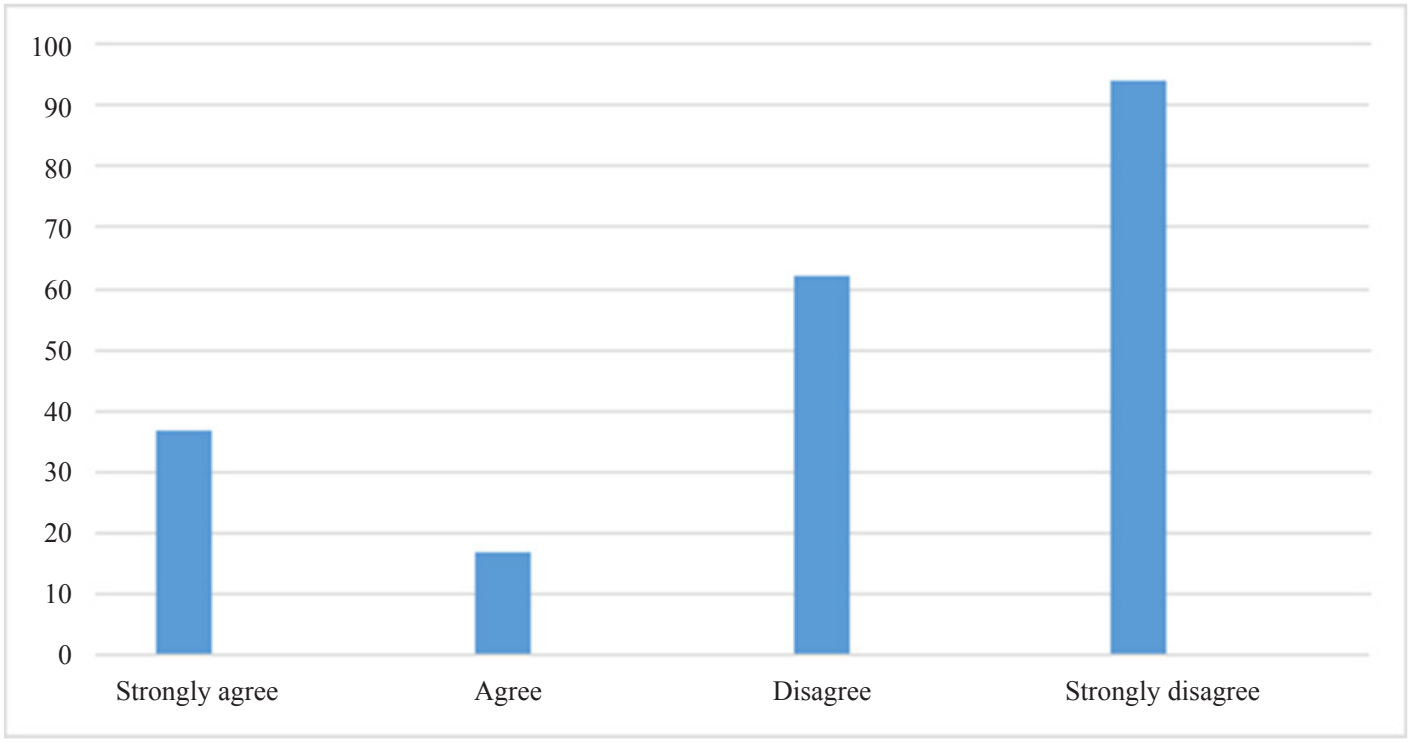

Source: Field Data (2021)

Figure 4. Frequency distribution on change of programme

Figure 4 indicates learners' willingness or unwillingness to amend their study program. The distribution above shows that most respondents were not willing to change their current study program. This coincides with Table 4, which indicates that most students were excited about their study programs. Conversely, some respondents were willing to change their study program when given the opportunity, although they are in the minority compared to those who are willing to continue with their study program.

\subsection{Reasons for selecting a particular programme}

The researcher seeks to identify factors influencing their choice of study. This was to understand the intrinsic and extrinsic motivations behind the choice of their study.

Figure 5 below depicts the reasons for the selection of a particular study course. 


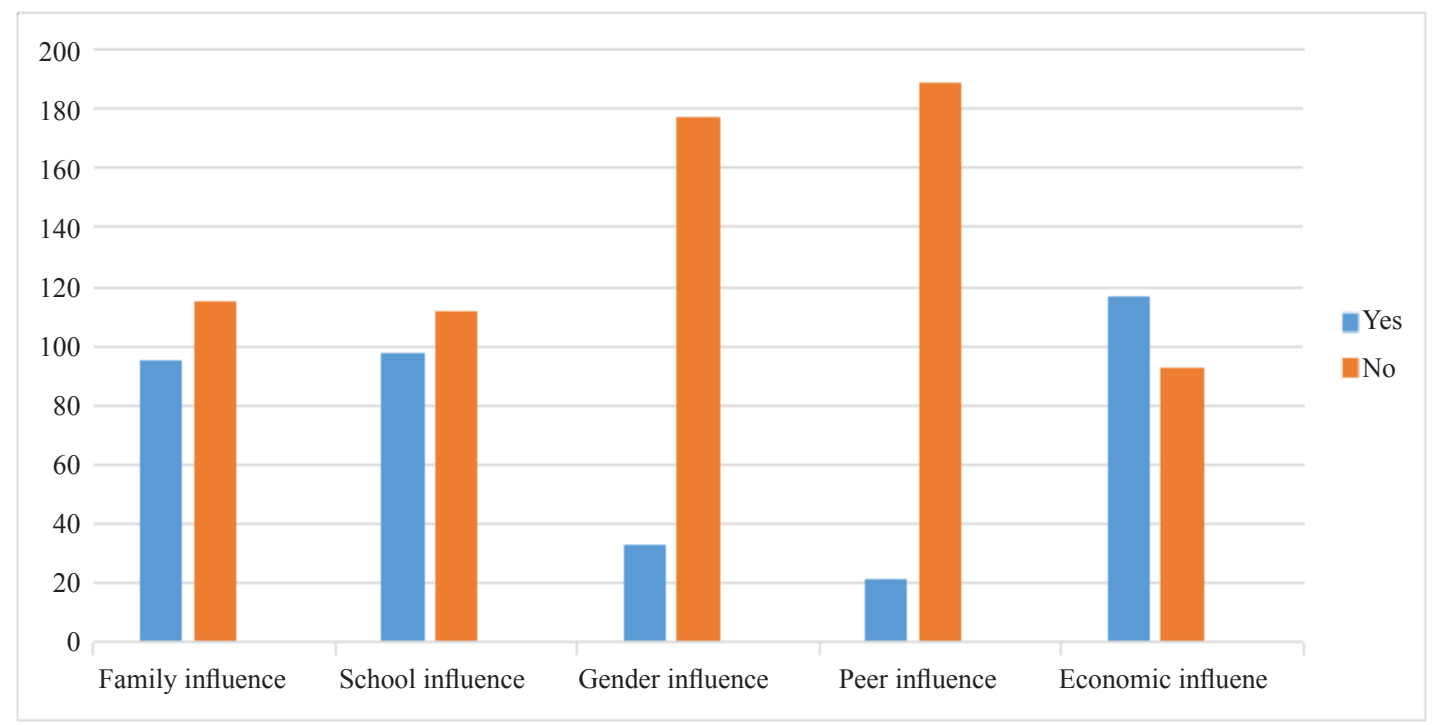

Source: Field Data (2021)

Figure 5. Frequency distribution on influencing factors

Figure 5 shows the frequency distribution of factors influencing the course of study. From the figure above, the majority of the learners were urged by their families to select courses of study. A proportion of students (45\%) have been urged by family in choosing the current course they are pursuing. This is because they feel it will help the family in the long run. In addition, some respondents were influenced by their families in choosing some courses because they perceived it as their family's choice.

However, more respondents, $98 \%$ or $46.7 \%$, were influenced by their former Senior High school (SHS), where various workshops on the selection of course of study at the higher education were organized. For example, school counselors and career exploration activities provided additional information about various course selections at the Universities. Despite the availability of these courses and activities, some respondents, 112 (53.3\%), were not influenced by their former schools.

Also, 21 respondents $(10.0 \%)$ were found to be urged by friends to select the current course of study, while as many as 189 respondents $(90 \%)$ were not urged by peers in selecting the course.

The study also found out that, job security was another influential factor in choosing a course of study among the respondents. From the frequency distribution above (Figure 5), it can be inferred that the majority of the respondents, 117 (55.7\%), were studying their current course for an easy access to job opportunities after graduation. In addition, they were studying the course to gain the necessary skills and knowledge to start their own careers after graduation. A good salary and incentives were among the reasons that influenced the choice of the course. On the contrary, 93 of the respondents $(44.3 \%)$ were not influenced by job security or a good salary for the future.

21 respondents (10.0\%) indicated that they were influenced by their peers to choose their current course of study, while as many as 189 respondents $(90 \%)$ were not influenced by their peers.

\section{Summary}

The paper investigated factors that urged the choice of study programs for undergraduate students at Valley View University, Kumasi. The research instruments used for data collection were questionnaires and field interviews.

The study considered 210 respondents from all levels (100-400). 210 questionnaires were used for analysis. A combination of stratified, quota sampling and lottery techniques was used to collect data from respondents. The data were analyzed and presented using frequencies and tables using SPSS V20. These data were summarized according to the results generated. 
The objectives of the study were firstly, to investigate the preferred study options for students in the College of Education at Valley View University. Secondly, to determine what urged the learners to select study programs of undergraduate in the Valley View University Kumasi campus. Finally to suggest ways to improve the preferred course of study for students.

\subsection{Preferred programme of study by students of the Valley View University, School of Education-} Kumasi

The results of the study show that most students prefer to study social studies, followed by English, religion, mathematics and accounting.

The study also found that $81.9 \%$ of students in the College of Education offer courses of study they prefer, while $18.1 \%$ offer courses they would like to change. The reason for this is that they are influenced by family members, peers and role models. We should work to overcome any percentage differences in external influences on students offering their preferred courses.

\subsection{The urge of students' selection of programmes for learners in the Valley View University (VVU), School of Education-Kumasi}

From the study, it was realized that, Students in the School of Education-Kumasi, VVU, were studying programmes as a result of Economic influence. Thus, there will be the availability of job opportunities, the easy establishment of businesses and jobs that can offer them greener pastures. It was also noticed that students were reading their programme of study through the influence of their various Senior High Schools. Schools with academic counselors, career exploration activities, and adequate orientation programmes have a tremendous influence on the student's selection of programme. The following were discovered; the family, peer groups and gender issues have minimal influence on the selection of programme of study among students. It was also realized that selection of programs of study by undergraduates' may lead to consequences such as unemployment and joblessness. The above may happen as a result of students offering the wrong course of study.

\subsection{Ways of improving students' access to their preferred courses of study}

From the study, it was noticed that students' access to their preferred program of study can be improved through:

First, Online learning offers flexibility. i.e. offer students to study on their own terms notwithstanding the financial strength of students and where they live. It improves digital literacy and helps create more student's intake which the traditional classroom setting would not be necessary.

Secondly, Academic Guidance. That is, students should seek academic advice from expects before embarking on the selection of the program for their area of study.

Furthermore, Orientation should be free and mandatory for all students to be given information by either the Head of Department or Institutional heads as a way to prepare the students and to give them in-depth knowledge of choice of programme and their academic carriers.

Also, Avoidance of Family Influence. The family should not influence students to read programmes they do not desire to study. They should rather serve as a guide to students in the selection of programmes of their choice.

\section{Conclusions}

From the discussion of the results, it can be concluded that strategies such as orientation, academic guidance, and avoidance of family influence should be developed to enhance students' selection of their preferred programs of study. Similarly, the study found that economic influence was a major factor that students considered when choosing a course of study. The other influencing factors such as family, peers, and gender were all found to be minor factors. 


\section{Recommendation}

First and foremost, Families should serve as guides and support their wards in the selection of courses rather than impose various programmes on them due to poverty.

In addition, Ghana Education Service (GES) should add guidance and counseling into the SHS syllabus to enhance prior knowledge on the selection of courses or programmes of study in the tertiary institutions and organization of career exploration activities to help them decide on the programme of study.

Lastly, since most students were found to be willing to study social studies, the department of social education should increase the number of students admitted on a yearly basis so that it can increase the number of students in the department to help produce good citizens to the country.

Also, proper guidance is required by parents, guidance and counseling coordinators and school authorities to guide undergraduates in their selection of courses of study to help reduce if not eradicate the high number of unemployed graduates in Ghana.

It is the wish of the researcher that this work will serve as a vital document and a fundamental principle to other researchers who would want to further work on the effect of the programme of study on undergraduates on Ghana's economy.

\section{Reference}

Akyina, K. O., Oduro-Okyireh, G., \& Osei-Owusu, B. (2014). Assessment of the rationality of senior high school students choices of academic programmes in Kwabre East District of Ghana. Journal of Education and Practice, 5(28), 15-19. https://iiste.org/Journals/index.php/JEP/article/view/16120/16319

Alberts et al. (2002). Factors Influencing Students Choice of programme (pp. 1616). New York: Garland Science.

Alika, I. H. (2010). Parental and peer group influence as correlates of career choice in humanities among secondary school students in Edo State, Nigeria. Journal of Research in Education and Society, 1(1), 178-185. https:// docplayer.net/44155286-Parental-and-peer-group-influence-as-correlates-of-career-choice-in-humanities-amongsecondary-school-students-in-edo-state-nigeria.html

American Psychological Association, Council of Representatives (1982). Ethical principles of psychologists. American Psychologist, 36(6), 633-638. https://doi.org/10.1037/0003-066X.36.6.633

Basow, S. A., \& Howe, K. G. (1979). Model influence on career choices of college students. The Vocational Guidance Quarterly, 27(3), 239-243. https://doi.org/10.1002/j.2164-585X.1979.tb00991.x

Blaikie, N. (2000). Designing Social Research. Cambridge: Polity Press. https://www.scirp.org/(S(351jmbntvnsjt1aadkposzje))/ reference/ReferencesPapers.aspx?ReferenceID $=654752$

Brown, B. B. (1982). The extent and effect of peer pressure among high school students: A retrospective analysis. Journal of Youth and Adolescents, 11(2), 121-133. https://doi.org/10.1007/BF01834708

Bryman, A., \& Bell, E. (2006). Business Research Methods. Oxford University Press, Oxford.

Carlo, G., Roesch, S. C., \& Melby J. (1998). The multiplicative relations of parenting and temperament to prosocial and antisocial behaviors in adolescence. Journal of Early Adolescence, 18(3), 266-290. https://doi. org $/ 10.1177 / 0272431698018003003$

Classen, R. D., \& Brown, B. B. (1985). The multi-dimentionality of pear pressure in Adolescence. Journal of Youth and Adolescence, 14, 451-468. https://link.springer.com/article/10.1007/BF02139520

Coetzee, M., \& Beukes, C. (2010). Employability, emotional intelligence and career preparation support satisfaction among adolescents in the school-to-work transition. Journal of Psychology in Africa, 20(3), 439-446. https://www. tandfonline.com/doi/abs/10.1080/14330237.2010.10820396

Creswell, J. W. (2003). Educational Research: Planning, Conducting, and Evaluating Quantitative and Qualitative Research (3rd ed.). Upper Saddle River, New Jersey: Pearson Education, Inc. https://www.researchgate.net/ publication/271429461_Educational_Research_Planning_Planning_Conducting_and_Evaluating_Quantitative and_Qualitative_Research

Creswell, J. W. (2009). Research Design: Qualitative, Quantitative, and Mixed Method Approaches. Thousand Oaks: SAGE Publications, Inc. https://psycnet.apa.org/record/2008-13604-000

Daily Graphic (2010, July 15th). Graduate Unemployment Association of Ghana.

Ellis, W., \& Zarbatany, L. (2007). Peer group status as a moderator of group influence on children's deviant, aggressive, 
and prosocial behavior. Child Development, 78(4), 1240-1254. https://www.jstor.org/stable/4620700

Fisher, T. A., \& Stafford, M. E. (1999). Reliability and validity of the Career Influence Inventory: A pilot study. Journal of Career Assessment, 7(2), 187-202. https://doi.org/10.1177/106907279900700207

Golafshani (2003). The scholastic aptitude test "explains" why college men major in science more often than college women. Journal of Counseling Psychology, 23, 50-54.

Hackett, G., Esposito, D., \& O'Halloran, M. S. (1989). The relationship of role model influences to the career salience and educational and career plans of college women. Journal of Vocational Behavior, 35(2), 164-180. https://doi. org/10.1016/0001-8791(89)90038-9

Holstein, J. A. \& Gubrium, J. F. (1997). Active Interviewing. In: Silverman, D. (Ed.), Qualitative Research: Theory, Method and Practice (pp. 113-129). Sage, London. https://www.scirp.org/(S(lz5mqp453edsnp55rrgjct55))/ reference/referencespapers.aspx?referenceid $=1477783$

Holsworth, D. W., \& Nind, D. (2006). Choice modelling New Zealand High School Seniors' Preferences for University Education. Journal of Marketing for Higher Education, 15(2), 81-102. https://doi.org/10.1300/J050v15n02_04

Kallio, R. E. (1995). Factors influencing the college choice decisions of graduate students. Research in Higher Education, 36(1), 109-124. http://hdl.handle.net/2027.42/43614

Kokaly, M. L. \& Nauta, M. M. (2001). Assessing role model influences on students' academic and vocational decisions. Journal of Career Assessment, 9(1), 81-99. https://doi.org/10.1177/106907270100900106

Maringe, F. (2006). University \& course choice: Implications for positioning, recruitment and marketing. International Journal of Educational Management, 20(6), 466-479. https://doi.org/10.1108/09513540610683711

McArdle, S., Waters, L., Briscoe, J. P., \& Hall, D. T. (2007). Employability during unemployment: Adaptability, career identity and human and social capital. Journal of Vocational Behavior, 71(2), 247-264. https://doi.org/10.1016/ j.jvb.2007.06.003

Ofori, R. \& Dampson, D. G. (2011). Research methods and statistics using SPSS. Payless Publication Limited, Amakom-Kumasi.

Pittenger, D. J. (2003). Internet research: An opportunity to revisit classic ethical problems in behavioral research. Ethics \& Behavior, 13(1), 45-60. https://doi.org/10.1207/S15327019EB1301_08

Sabir, R. I., Ahmad, W., Ashraf, R. U., \& Ahmad, N. (2013). Factors affecting university and course choice: A comparison of undergraduate engineering and business students in central Punjab, Pakistan. Journal of Basic and Applied Scientific Research, 3(10), 298-305. https://www.textroad.com/pdf/JBASR/J.\%20Basic.\%20Appl.\%20 Sci.\%20Res.,\%203(10)298-305,\%202013.pdf

Sanchez, J. S. (2012). Factors influencing a student's decision to pursue a communications degree in Spain. Intangible Capital, 8(1), 43-60. http://dx.doi.org/10.3926/ic.277

Schreuder, A. M. G., \& Coetzee, M. (2011). Careers: An Organisational Perspective (4th ed.). Cape Town: Juta. https:// www.worldcat.org/title/careers-an-organisational-perspective/oclc/864900415 